\title{
STUDY OF LANDCOVER/LANDUSE IN SHARAZUR PLAIN BY USING REMOTE SENSING TECHNIQUES
}

\author{
Ahmad S. Al-Mashhadani \\ College of Agriculture \\ Baghdad University, Iraq
}

\author{
Dalshad R.Azeez* \\ College of Agriculture \\ Kirkuk University, Iraq
}

\author{
Mahtab H. S. Faqi Qadir \\ College of Agricultur \\ Sulaimany University,Iraq
}

\begin{abstract}
The study area, is forming a part of the Sulaimani Governorate, in the North-east part of Iraq approximately between latitude $35^{\circ} 10^{\prime}-35^{\circ} 28^{\prime} \mathrm{N}$ and longitude $45^{\circ} 35^{\prime}-46^{\circ} 20^{\prime} \mathrm{E}$. , The objective of the study is to determine the dominant landuse/landcover types in Sharazur plain by using remote sensing techniques.

The results indicated that there are 12 classes of landuse/landcover, class (9) which represented canals and ditches was the smallest area (306.41ha) form the $0.072 \%$ of total area, while class (6) represents vegetation 3 is the largest part from Sharazur plain with about (114590.88ha) form the $26.85 \%$ of total area. Also the research showed that the most abundant landcover in studied area was vegetation which consists about $38.11 \%$ of Sharazur area. The bare soils followed after vegetation by consisting of $35.11 \%$ of studied area. Water is a third landcover in Sharazur which consists of about $4.2 \%$ of the studied area with about (17940.14)ha. Also the distribution pattern of urban group which includes roads and residential in the study area represents $(2.35 \%)$ of the total areawith an area of (10033.82)ha, While the distribution pattern for of agricultural group which includes vegetation1, vegetation 2 and vegetation 3 consists of the highest part of Sharazur plain with an area of (162639.8)ha with about $38.11 \%$ of total area,but group 4 represents different soils represents about (35.11\%) with total area of (149850.66)ha
\end{abstract}

\section{INTRODUCTION}

Landuse is obviously constrained by environmental factors such as soil characteristics, climate, topography, and vegetation. But also reflects the importance of land as a key and finite for most human activities including agriculture, industry, forestry, energy production, settlement, recreation, and water catchments and storage (Nagamani and Ramachandran,2003). Land is a fundamental factor of production, and through much of the course of human history, it has been tightly coupled with economic growth. Often improper landuse causes various forms of environmental degradation. For sustainable utilization of the land ecosystems, it is essential to know the natural characteristics, extent and location, its quality, productivity, suitability and limitations of various landuses.

Landuse is a product of interactions between a society's cultural background, state, and its physical needs on the one hand, and the natural potential of land on the other (Balak Ram and Kolarkar-1993). The term landcover relates to the type of feature present on the surface of the earth such as lake, maple trees, high ways, while landuse relates to the human activity or economic function associated with a

The research is a part of the Msc. thesis of the third researcher Received 10/3/2008 accepted 19/6/2008 
specific piece of land. Landcover is a fundamental parameter describing the earth's surface. This parameter is a considerable variable that impacts on and links many parts of the human and physical environments (Foody, 2002).Although the terms landcover and landuse are often used interchangeably, their actual meanings are quite distinct. Landcover refers to the surface cover on the ground, while Landuse refers to the purpose of the land serves. Landuse describes how a parcel of land is used (such as for agriculture, residences, or industry), whereas landcover describes the materials (such as natural vegetation, rocks, or buildings) that are present on the surface. The landcover of an area may be evergreen forest, but the landuse may be lumbering, recreation, oil extraction, or various combination on land use and cover is essential for many planning activities.

Remote sensing is the science and the art of obtaining information about an object, area, or phenomenon through the analysis of data required by a device that is not contact with the object, area or phenomenon under investigation (Lillesand and Kiefer, 1994). The properties measured with remote sensing techniques relate to landcover, from which land use can be inferred (Levin,1999).Williams (1992) performs a unique vegetation classification, using remote sensing in Peter Lougheed Provincial Park of the Kananaskis Valley. Spectral data from Landsat - 5 Thematic Mapper (TM) with (7-band data) is used in the provincial park. His goal was to determine the best set of classification variables to map the vegetation communities in the mountainous region.Coleman et al.(1993) found that six types of landcover are identified with $100 \%$ accuracy, and two identified with $88.9 \%$ by using T.M. while, Hamdi et al. (1991) divide soils of Alinebra-Egypt into soil orders (Aridisol and Entisols) using images of Landsat-4 for MSS sensor and Spot.

Remote sensing technique has ability to represent of landcover categories by means of classification process. With the availability of multispectral remotely sensed data in digital form and the developments in digital processing, remote sensing supplies a new prospective for landcover/landuse analysis (Bektas and Goksel, 2004). Within the framework of their study for the detection of possible landcover in Gökceada using Landsat TM data Bektas and Goksel(2004) showed that the remote sensing was found to be effective in evaluating urbanization impact for future land development project of study areas. To study the interrelationship between landuse/landcover change and land degradation over two different Mediterranean sites are investigated using remotely sensed and ancillary data (Symeonakis et al., 2005), showed increased susceptibility to runoff and erosion mostly for those areas are forest fires, urbanization, and/or overgrazing are the main causes of change and suggest that mitigation measure should be taken for the prevention of further degradation.

\section{MATERIALS AND METHODS}

Location Area: The study area, forming a part of the Sulaimani Governorate, in the North-east Iraq which is located between latitude $35^{\circ} 10^{\prime}-35^{\circ} 28^{\prime} \mathrm{N}$ and longitude $45^{\circ} 35^{\prime}-46^{\circ} 20^{\prime}$ E. The total area of Sharazur Plain is 76500 ha (Fig. 1 ) .

Climate: The Sharazur area lies at an elevation of 742 to $853 \mathrm{~m}$ above the m.s.1. and is characterized by a series of NW-SE trending ridges which become progressively 
higher towards the NE. the ridges force the cyclonic storms from the west to rise thus causing a large increase in precipitation in this area as compared to the central and southern sectors of Iraq .The mean annual precipitation in the area varies from about $700 \mathrm{~mm}$ in the NW to about $900 \mathrm{~mm}$ in the SE.

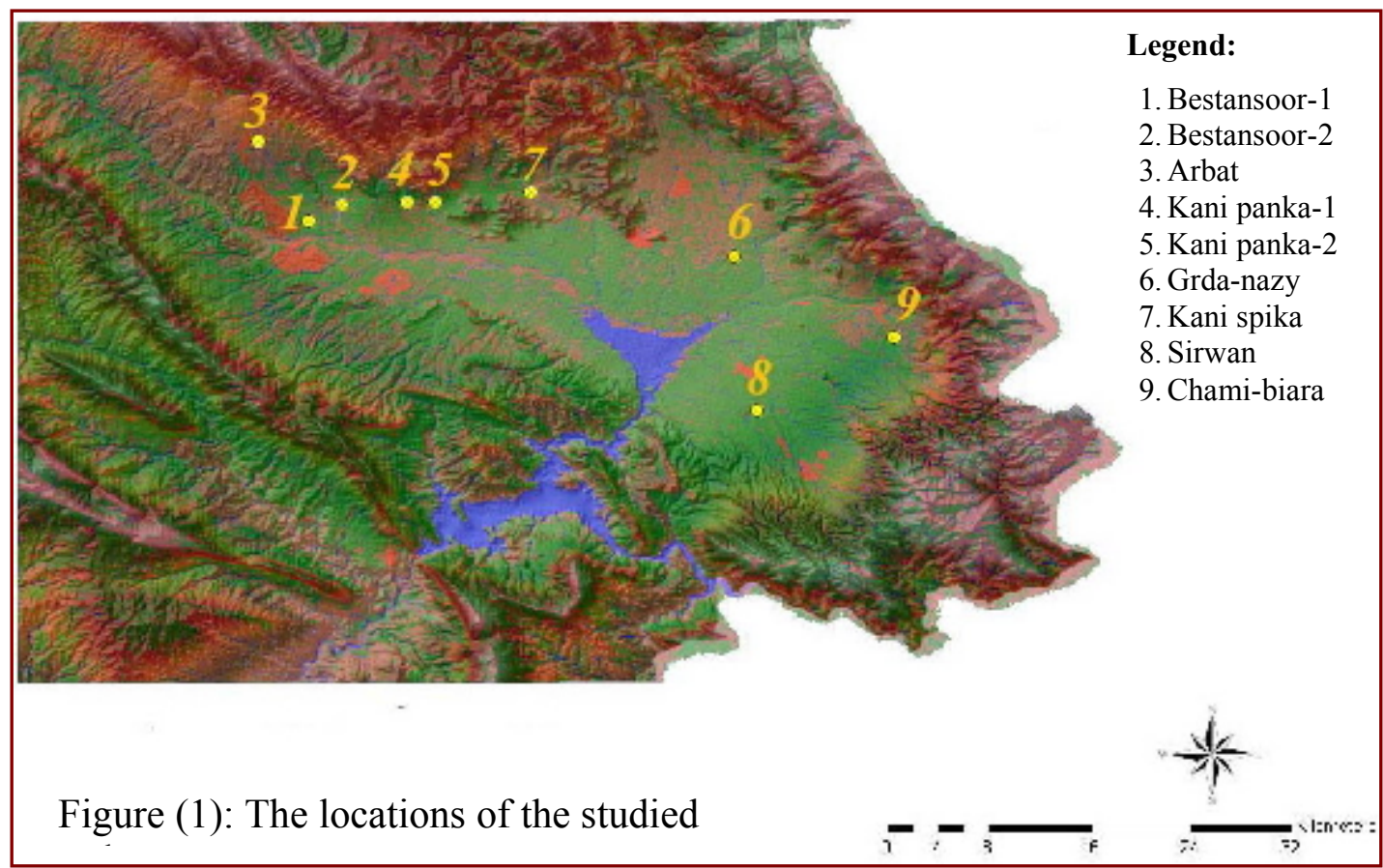

Image source: Image of Landsat-7 taken by Thematic mapper sensor (TM) in 13/9/2000 covering an area of (426785.7)ha including the study area with resolution $30 \mathrm{~m} \times 30 \mathrm{~m}$, is used for visual and digital interpretation in this study. Image interpretation and analysis are done by using false color composite of band blue with wave length $(0.45-0.52) \mu \mathrm{m}$, green $(0.52-0.60) \mu \mathrm{m}$ and red $(0.63-0.69) \mu \mathrm{m}$ (Fig.2), and image classification by using ERDAS V-9.0 program. The study area is divided in to 12 classes including the most dominant landuse/landcover variations. The variation in the image characteristics like tone, texture, pattern etc. is used to identify various landuse classes. The information obtained from the imagery is transferred to base map prepared from topographical map.

\section{RESULTS AND DISCUSSION}

Image classification and interpretation: Image interpretation refers to the examination and the transformation of remote sensing raw data into usable information. It involves the detection, identification and classification of the earth's surface characteristics for the purpose of collecting the needed information about certain phenomena and judging their significance.

The results of supervised classification using ERDAS V-0.9 recognized seven classes represent different types of landuse/landcover in the study area (Fig.3). These classes represent the most dominant landuse/landcover including water body, different types of vegetations, land bare and different soil types (Tab.1). The results indicated that the dominant land cover was (class 2) which represents of soil 2 class. These soils were investigated by there high amount of $\mathrm{CaCO}_{3}$, silty clay 


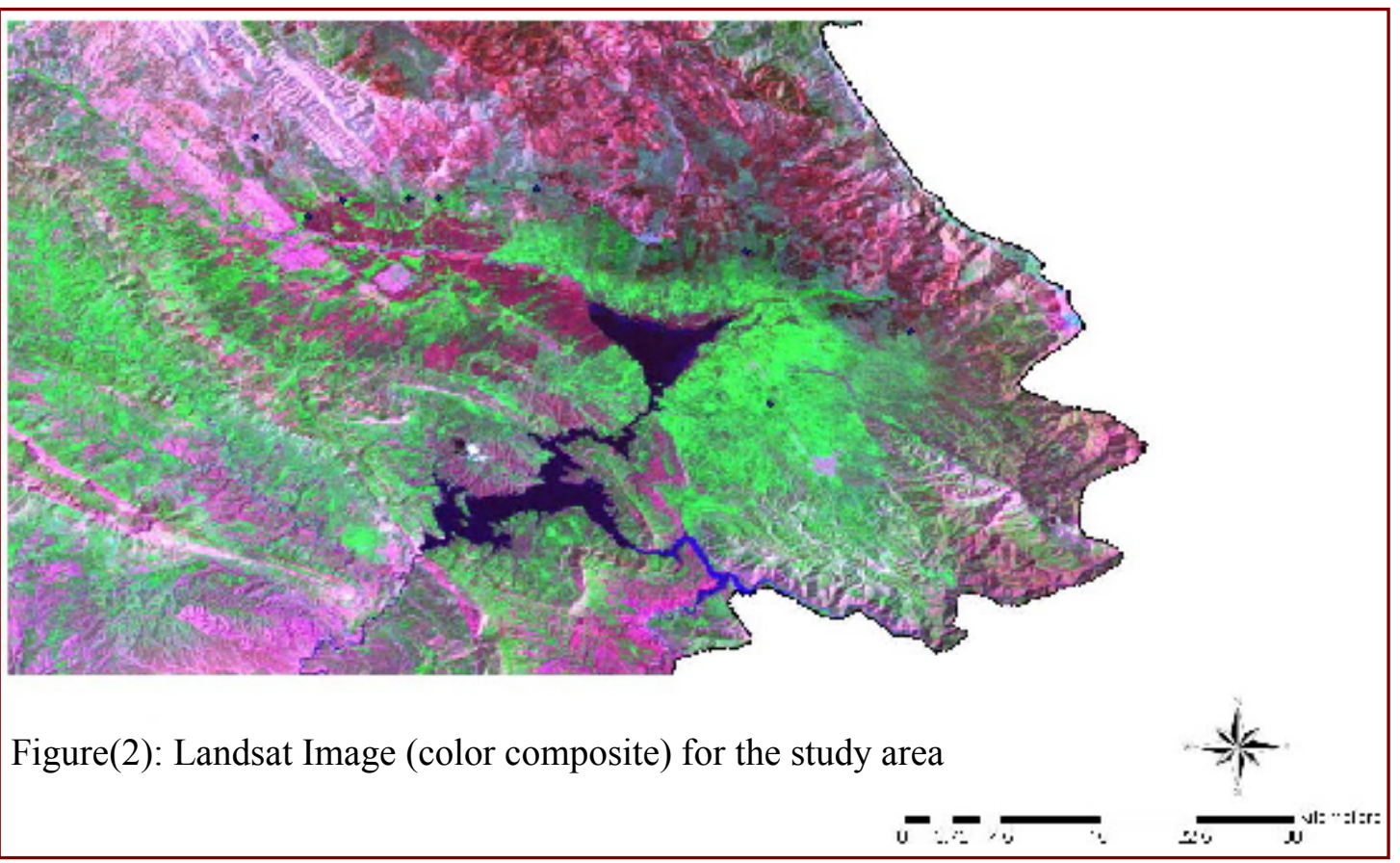

- color composite of band blue (0.45-0.52) $\mu \mathrm{m}$, green $(0.52-0.60) \mu \mathrm{m}$ and red (0.63$0.69) \mu \mathrm{m}$

- image dated in 13/9/2000

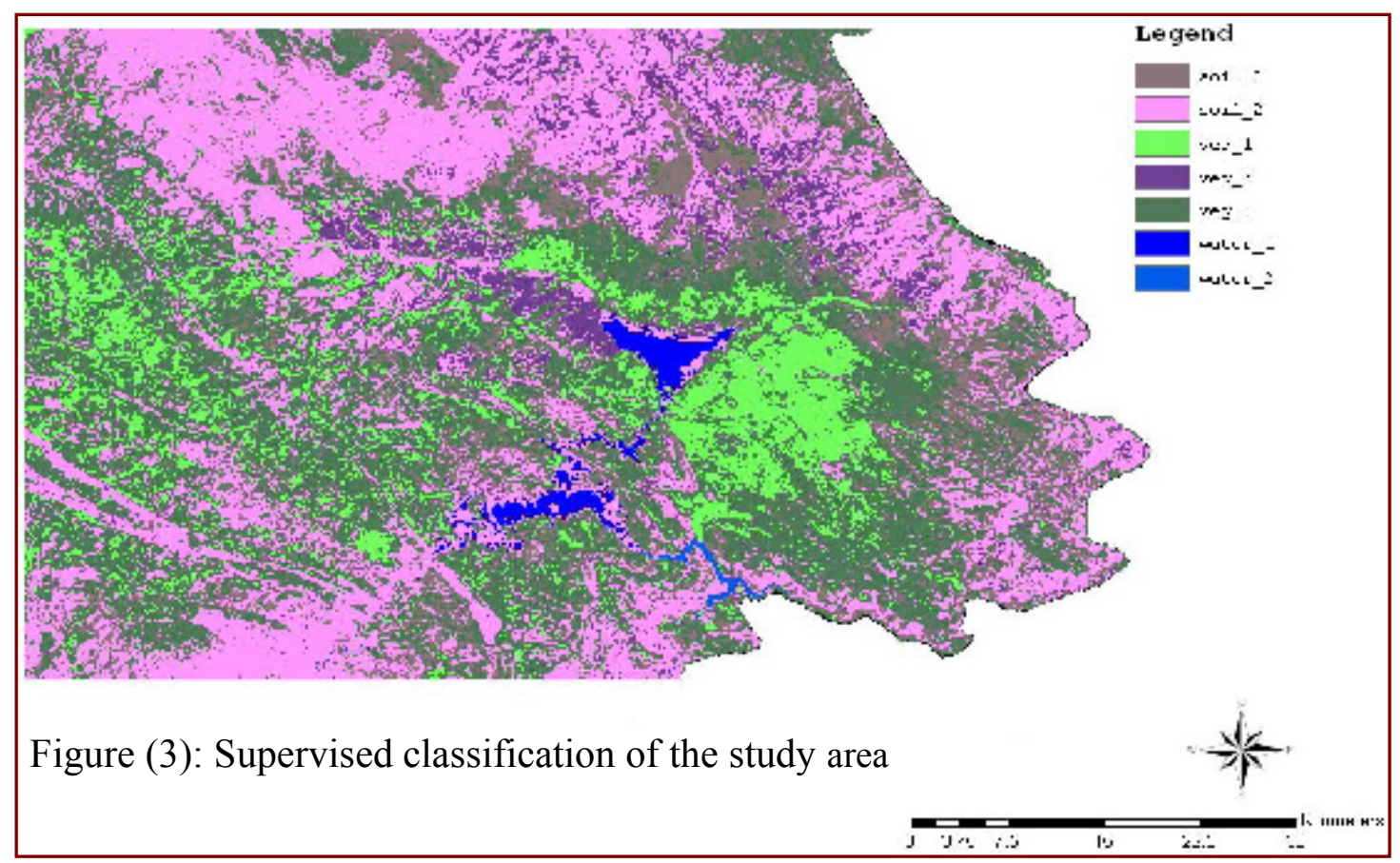

texture of surface horizons, indicated that these soils are cultivated during all the seasons of the year. Class 3 which includes vegetation1 followed this class is a pasture area. The (class 5) which represents landuse/landcover of vegetation 3 which is the cultivated area vegetated by (Sinapis arvesis, Carthamus oxycanthus, 
Table (1): The dominant landuse/landcover in the studied area

\begin{tabular}{|c|l|}
\hline $\begin{array}{c}\text { No. } \\
\text { classes }\end{array}$ & \multicolumn{1}{|c|}{ Type of land cover } \\
\hline 1 & $\begin{array}{l}\text { Soil1 (soils with low amount of } \mathrm{CaCO}_{3}(4.6 \%), \text { stoniness, clayey } \\
\text { texture, low vegetation cover less than } 10 \%)\end{array}$ \\
\hline 2 & $\begin{array}{l}\text { Soil2 (soils with high amount of } \mathrm{CaCO}_{3}(13.97 \%), \text { silty clay texture, the } \\
\text { soil is cultivated all of the seasons during the year) }\end{array}$ \\
\hline 3 & Veg1 (pasture area) \\
\hline 4 & Veg2 (natural vegetations, forests, cereal crops, leguminous) \\
\hline 5 & Veg3 (natural vegetations, cereal crops, leguminous) \\
\hline 6 & Water1 \\
\hline 7 & Water2 \\
\hline
\end{tabular}

Lathyrus vinealis, Medicago hispida, Ammi majus, Lagonychum farctum, Convolvulus arvensis, Heliathus annus, Triticum aestinum, Hordeum vulgare, Cucumis dodaria) then (class 4) which includes vegetation 2 which is the cultivated area vegetated by (Silybum marianum, Sinapis arvesis, Ammi majus, Carthamus oxycanthus, Hordeum spoutaneum. Cicer arietinum, Triticum aestinum, Hordeum vulgare, Lens eseulenta, Cucumis dodaria, Platanus orientalis) then fallowed by bare soil (class1) which is characterized by the low amount of $\mathrm{CaCO}_{3}$, stoniness, clayey texture, low vegetation cover less than $10 \%$ of the area, then (class 6) which includes water 1, while water 2(class 7).

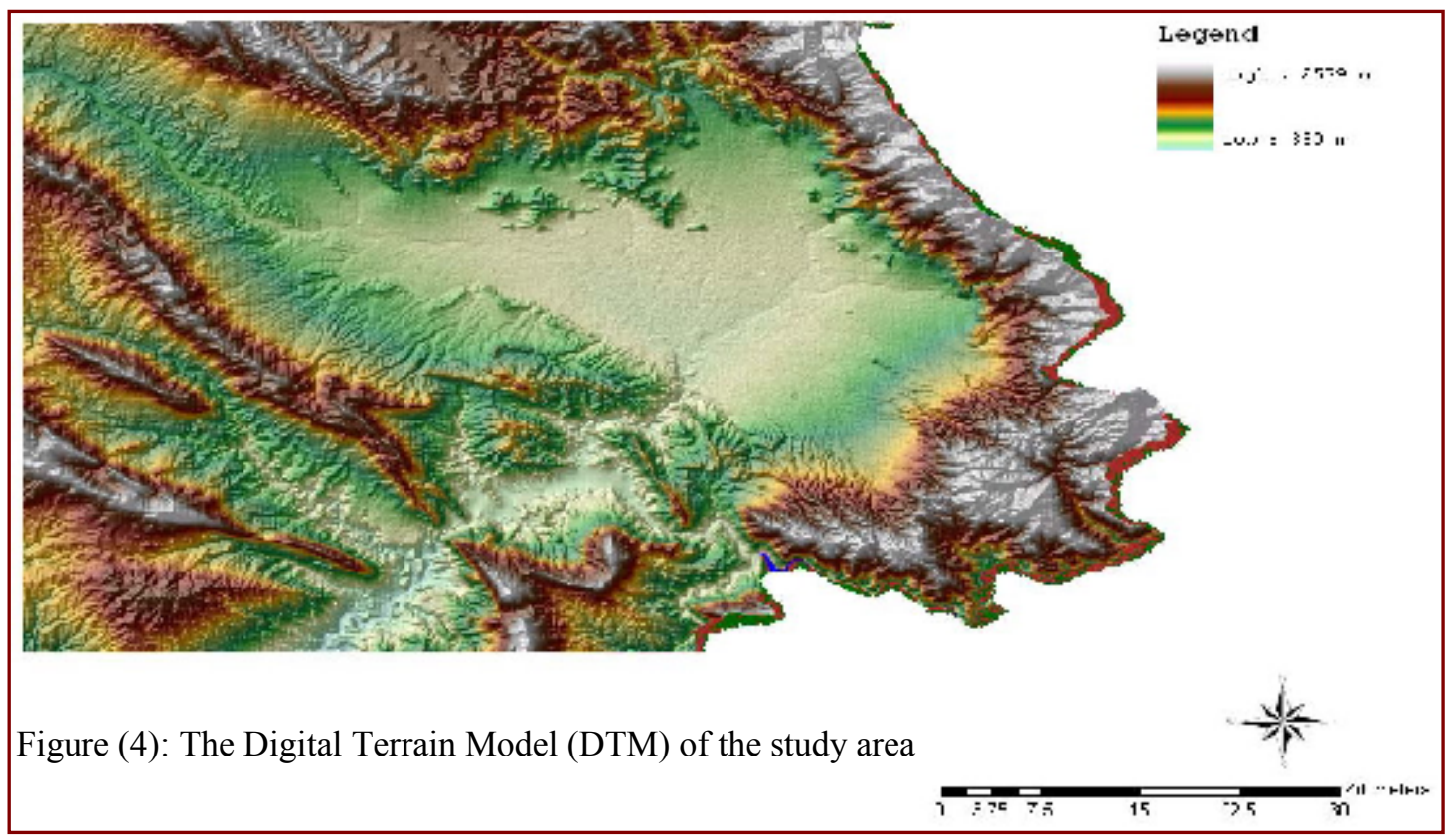




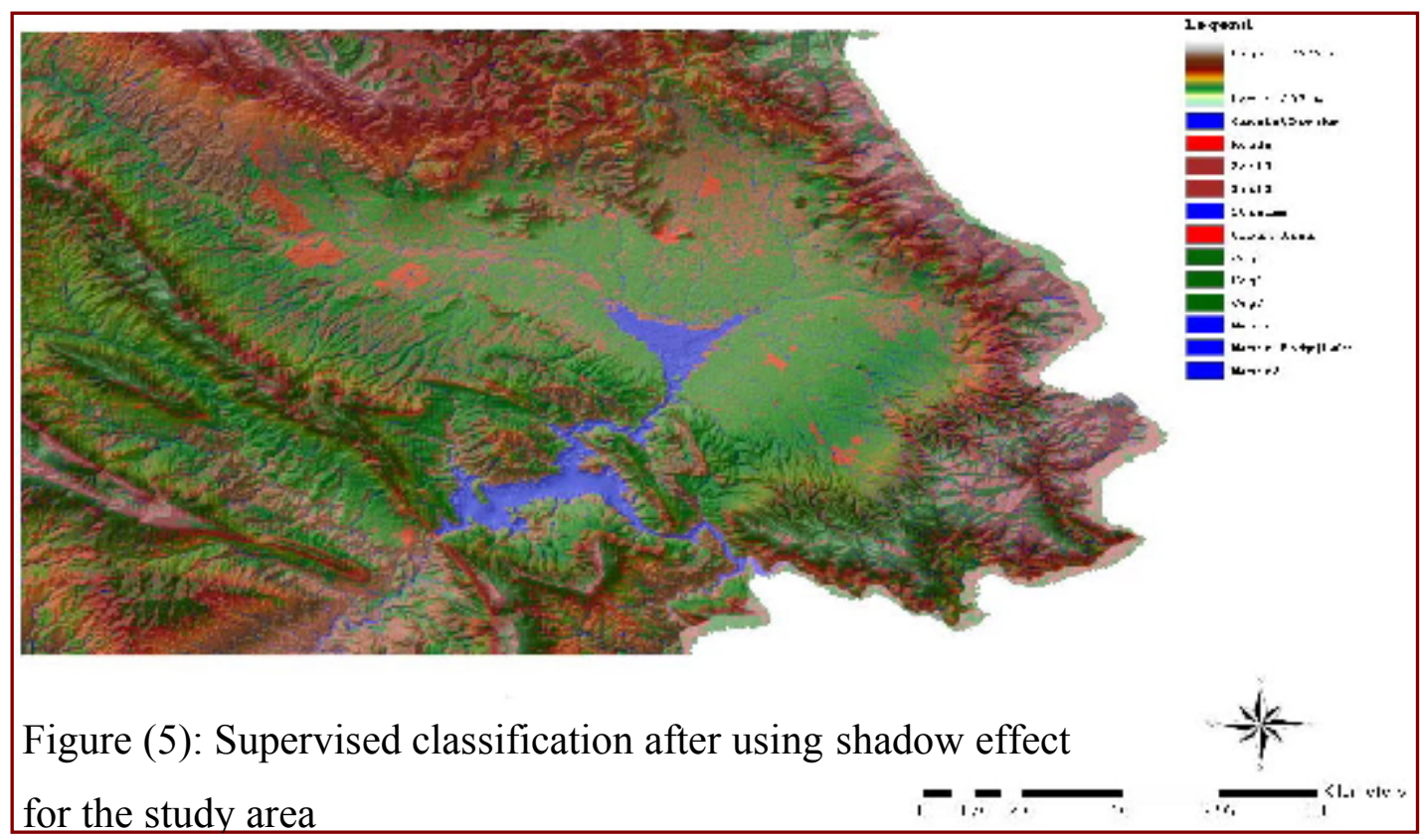

Consists the lowest percentage from total area.To make the results more accurate representative for all types of landuse/landcover present within Shahrazur plain, other layers of information including streams, canals, roads and shadow effect (Fig.4,5) are used in analyzing and classification of image by using ERDAS programsThe results of supervised classification by using ERDAS program show that there are 12 classes of landuse/landcover (Fig.6 and Tab.2).

The results indicate that class (9) which represents canals and ditches consists the smallest area (306.41)ha from the $0.072 \%$ of total area, while class (6) represents vegetation 3 consists the larger part from Sharazur plain with about (114590.88)ha from the $26.85 \%$ total area.

As mentioned in (Tab.2) and (Fig.6) the most abundant land cover in studied area is vegetation which consists about $38.11 \%$ ( vegetation1, vegetation 2 and vegetation 3) of Sharazur area. The bare soils followed after vegetation by consisting of $35.11 \%$ (soil 1 and soil 2) of studied area. This means that most parts of Sharazur still last years is important to cereal production or pasture. Water is a third landcover in Sharazur which consists of about $4.2 \%$ (water1,water2,canales, streams and Lake) of the studied area, the highest area of water is due to Darbendikhan lake which includes $37.89 \%$ from the water land cover.

Grouping of landcover/landuse classes : USGS system as described by Anderson et al.(1976) was used to classify Landuse/landcover. Fig.(7) shows the distribution patterns of water bodies area within Shahrazur plain including lake, streams, canals and ditches. All related water areas are represent (4.204\%) from the total area with about (17940.14)ha. Also (Fig.8) shows the distribution pattern of urban group which includes roads and Residential in the study area. Roads and urban consist of (2.35\%) from the total area with an area of (10033.82)ha,while (Fig.9) shows the distribution pattern for parts of agricultural group which includes vegetation 1 , vegetation 2 and vegetation 3 . The results indicate that the agricultural 
Table(2): Landuse/landcover classes in the study area

\begin{tabular}{|c|l|c|c|}
\hline $\begin{array}{r}\text { Clas } \\
\text { s } \\
\text { No. }\end{array}$ & \multicolumn{1}{|c|}{ land use/land cover type } & Area (ha) & $\%$ \\
\hline 1 & Water1 & 395.95 & 0.09 \\
\hline 2 & Vegetation 1 (pasture area) & 33391.44 & 7.82 \\
\hline 3 & $\begin{array}{l}\text { Vegetation 2 (natural vegetations, forests, } \\
\text { cereal crops, leguminous) }\end{array}$ & 14657.48 & 3.43 \\
\hline 4 & $\begin{array}{l}\text { Soil 1 (soils with low amount of CaCO } \\
\text { (4.60\%), stoniness, clayey texture, low } \\
\text { vegetation cover less than 10\%. }\end{array}$ & 43206.98 & 10.12 \\
\hline & $\begin{array}{l}\text { Soil 2 (soils with high amount of CaCO } \\
\text { (13.97\%), silty clay texture, the soil is } \\
\text { cultivated all of the seasons during the } \\
\text { year) }\end{array}$ & 106643.68 & 24.98 \\
\hline 6 & $\begin{array}{l}\text { Vegetation 3 (natural vegetations, cereal } \\
\text { crops, leguminous) }\end{array}$ & 114590.88 & 26.85 \\
\hline 7 & Water 2 & 396.92 & 0.09 \\
\hline 8 & Urban Area & 2669.48 & 0.62 \\
\hline 9 & Canals/Ditch's & 306.41 & 0.07 \\
\hline 10 & Lake & 6797.61 & 1.59 \\
\hline 11 & Roads & 7364.34 & 1.72 \\
\hline 12 & Streams & 10043.25 & 2.35 \\
\hline \multicolumn{2}{|l|}{ Unclassified are } & 86321.26 & 20.22 \\
\hline \multicolumn{2}{|l|}{426785.7} \\
\hline
\end{tabular}

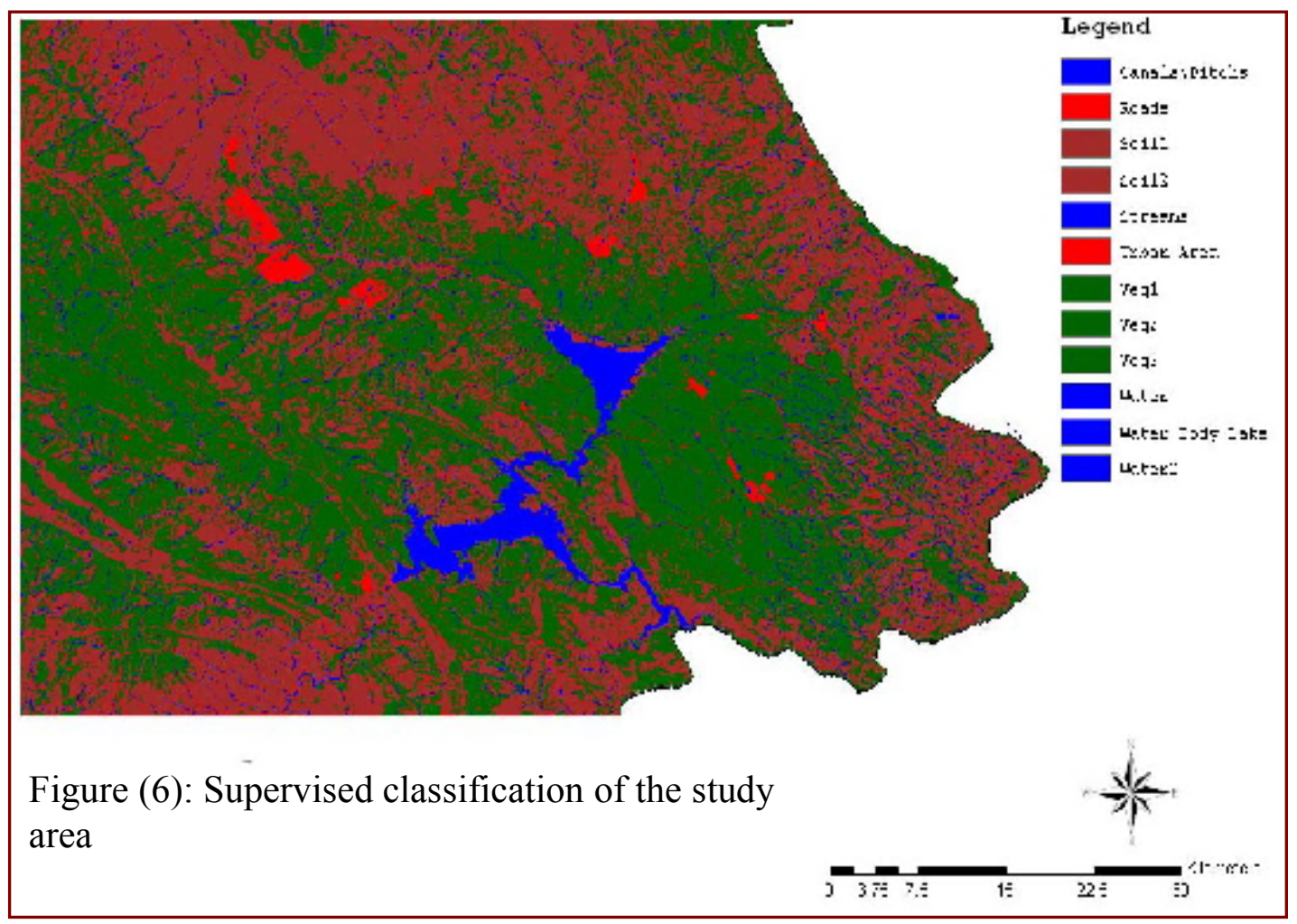




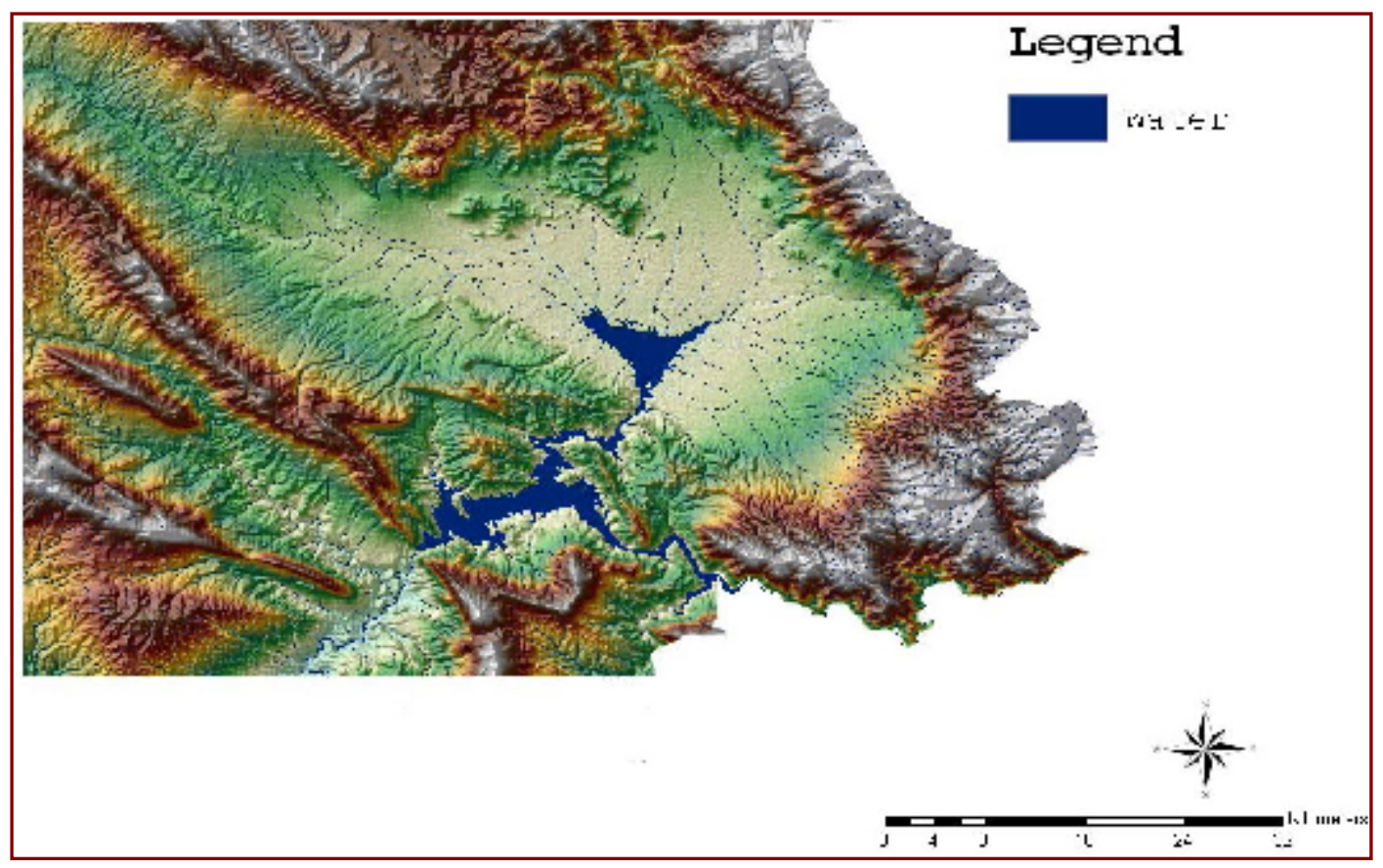

Figure (7): The distribution of water body within study area, and perspective view showing clear distinction of mountain and drainage pattern by using shadow effect method.

group includes the highest part of Sharazur plain with an area of (162639.8)ha with about $38.11 \%$ of total area.while group 4 represents different soils consist about (35.11\%) with total area of (149850.66)ha (Fig.10) .According to our field visiting we detected differences between classes in the area and there is human activity for civilization that is indicate it was affected by human activities .

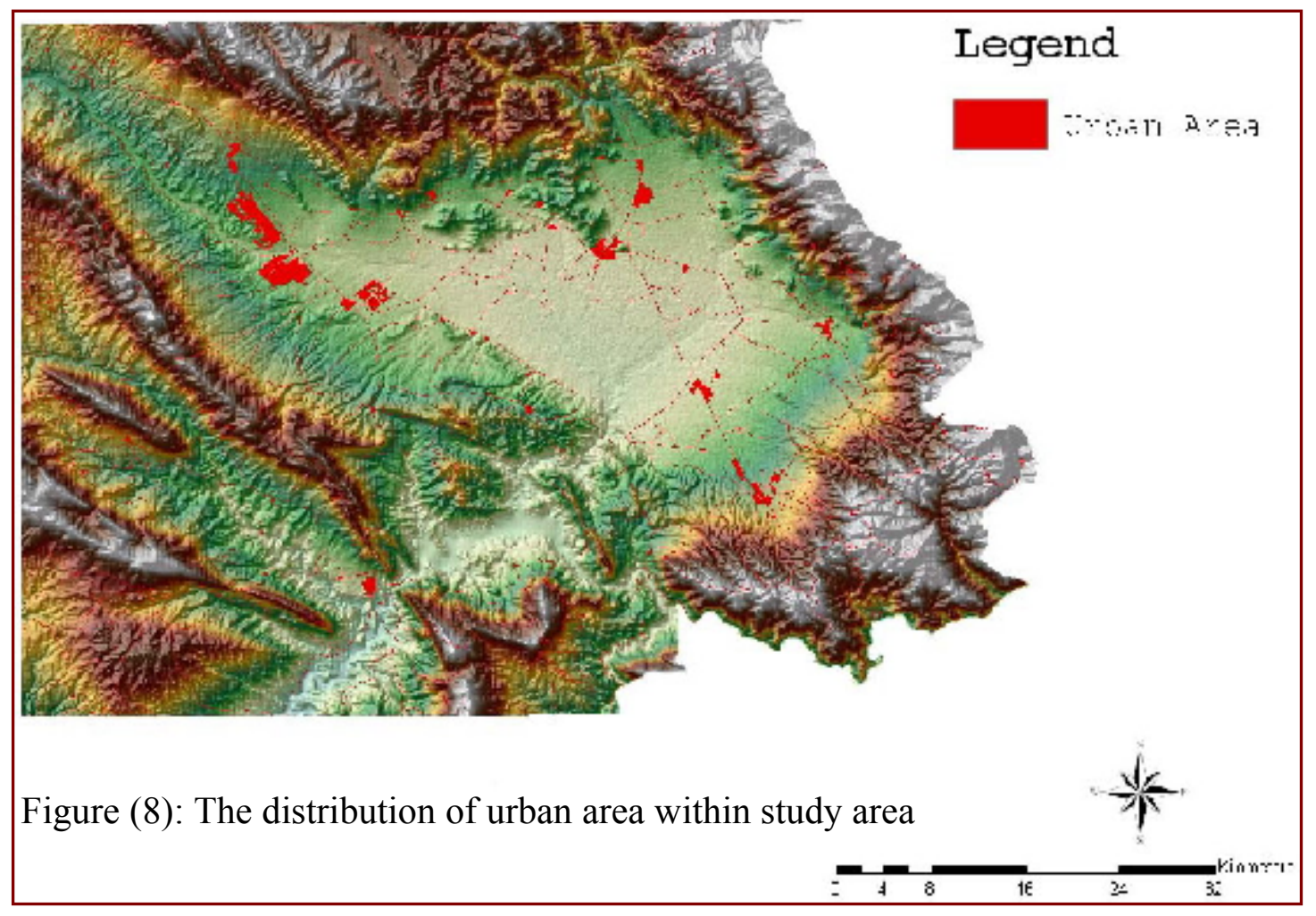



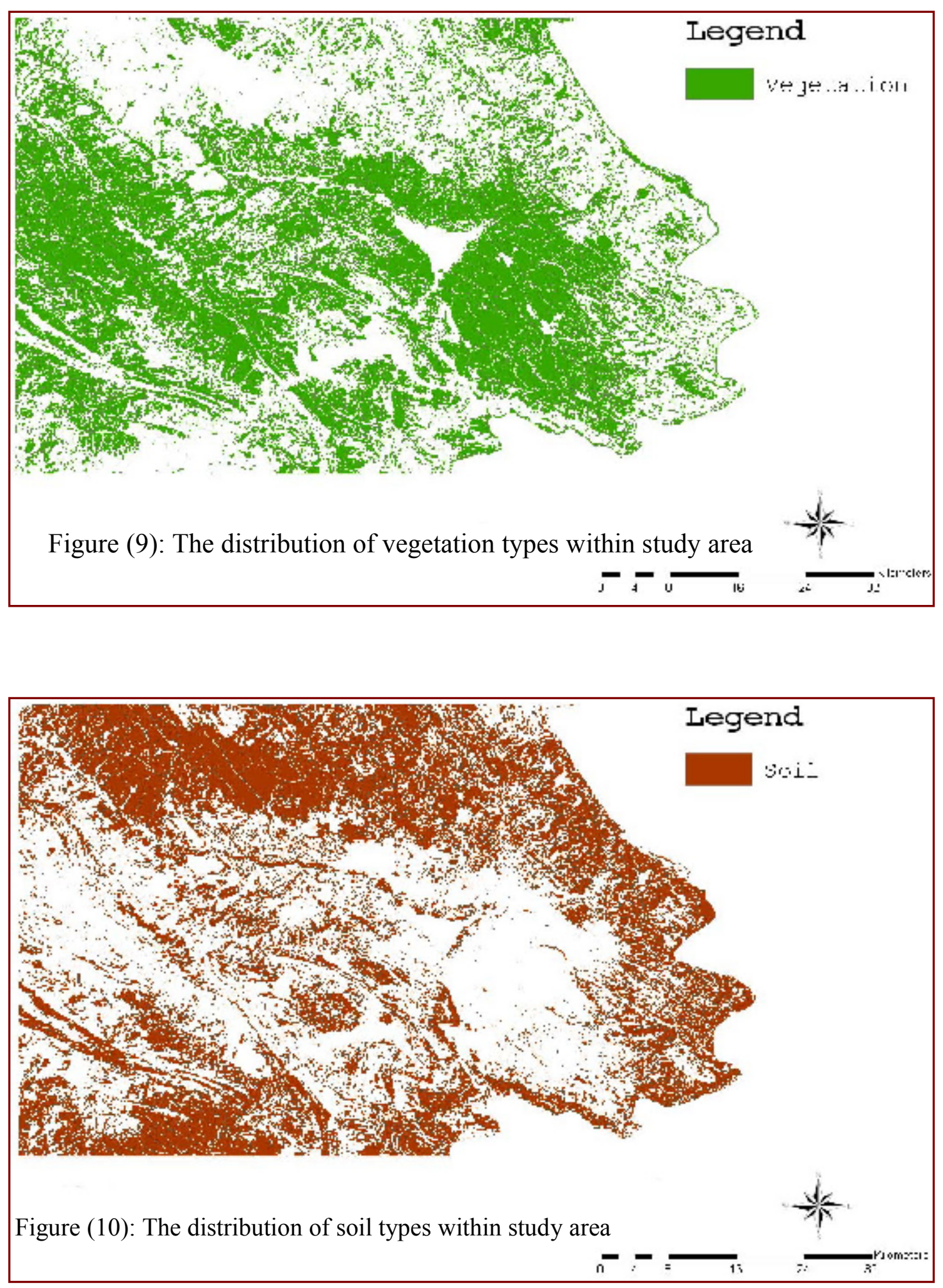


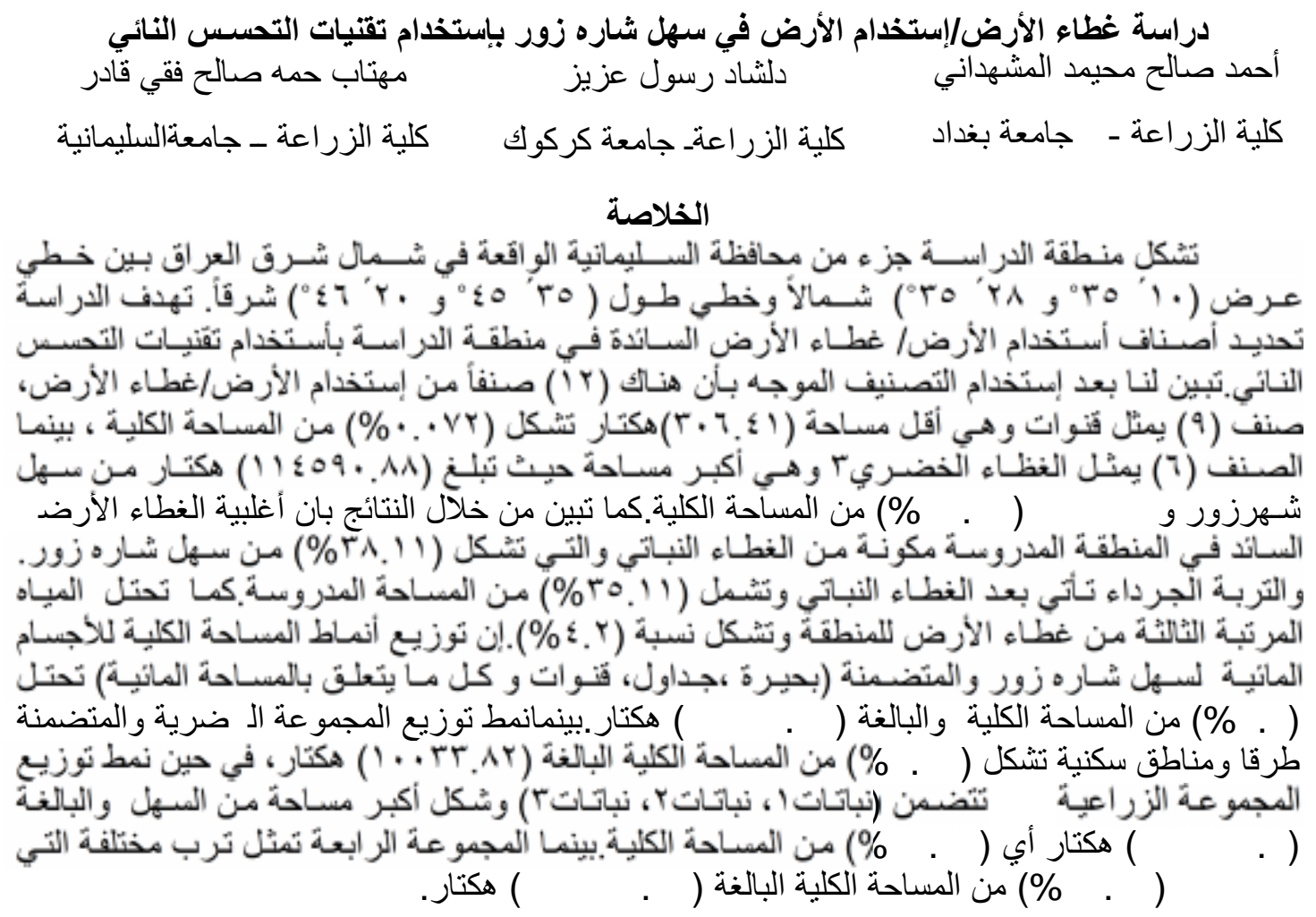

\section{REFERENCES}

Anderson, J.R., E.E. hardy, J.T. Roach, and R.E. Witmer (1976). A land-use and landcover classification system for use with remote-sensor data. U.S. Geological Survey. Reston, va. Professional Paper 964, 28pp.

Balak Ram and Kolarkar A.S., (1993). 'Remote Sensing application in monitoring land use changes in arid Rajasthan'.Int. J. Remote sensing,14.(17):3191- 3200

Bektas, F. and C.Goksel(2004).Remote sensing and GIS integration for land cover analysis, A case study: Gokceada Island. ITU, Civil Engineering Faculty, 34469Maslak Istanbul, Turkey Istanbul Coleman, T. L., P. A. Agbu, and O. L. Montgomery(1993).Spectral Differentiation of Surface Soil And Soil Properties: Is It Possible From Space Platforms? Soil Science 155(4): 283-291.

Foody, P.M.( 2002). Status of land cover classification accuracy assessment. Remote Sensing of Environment, 80: 185-201.

Hamid, A.A.; F.M Hawela and H.M. EL- Khattib (1991). Detection of surface soil variation using different resolution satellite data. Egyp J. soil Sc. 31:483488.

Levin, N., November(1999). Fundamentals of Remote Sensing.

Lillesand, T.M and Kiefer R.W.(1994).Remote Sensing and Image Interpretation, Third Edition: John Wiley and Sons Inc, Inc.: Toronto.

Nagamani, K and S.Ramachandran(2003). "Landuse/Land cover in pondicherry using remote sensing and GIS" in Martin J. Bunch, V. Madha Suresh and T. Vasantha Kumaran, eds.,Proceedings of the Third International Conference on Environment and Health, Chennai, India, 15-17 December.

Symeonakis, E., S. koukoulas, a Calvo-Casses, E. Arnau-Rosalen and I.Makkris(2005). A landuse change and land degradation study in Spain and Greece using remote sensing and GIS. Dept. of Geography, University of the Valencia, Valencia 46010, Spain.

Williams, J.A. (1992). "Vegetation Classification Using Landsat TM and SPOT- HRV Imagery in Mountainous Terrain, Kananaskis Country, .W. Alberta". 